\title{
The Cycles Of The Accounting Cycle
}

John A. Rude, (E-mail: jrude@bloomu.edu), Bloomsburg University

\begin{abstract}
Early in the first course in financial accounting, students learn the accounting cycle. The accounting cycle is very simple. It is just a list of the basic actions of accountants that lead to the financial statements. However, students beginning the study of accounting seem to find it difficult to understand and remember. I believe the difficulty stems from the way is which the accounting cycle is presented in accounting texts. In this paper, I reviewed principles of accounting and financial accounting texts and some intermediate accounting texts to summarize the way the accounting cycle is currently presented. I then proposed a method of teaching the accounting cycle that focuses on the substance of the steps, not just their form. I further proposed that this method be used as a framework to teach many of the subjects in financial accounting. Lastly, I surveyed accounting students regarding the presentation of the accounting cycle. The results have been very favorable.
\end{abstract}

\subsection{The Introductory Cycle}

$\mathrm{T}$

he first four or five chapters of most beginning accounting text books cover the accounting cycle. The remainder of the text material continues with cash and proceed through the assets and liabilities on the balance sheet and related income statement accounts. Somewhere in those first four or five chapters, the accounting cycles is covered by listing and explaining the steps. Over the years, I noticed that each text seems to have a different view of what the steps are. My students in the last intermediate accounting course also have a different view of the steps in the accounting cycle, perhaps because they have seen at least two versions of the accounting cycle; one in their principles text and one in their intermediate accounting text.

Since the Accounting Education Change Commission asked those who teach accounting to think innovatively, I have tried to do so. In regard to the accounting cycle I have developed an approach that I believe is simple, easy to remember, and may provide a framework for learning many of the topics in financial accounting.

The purpose of this paper is to review principles of accounting, financial accounting and intermediate accounting texts to determine the various presentations of the accounting cycle. I then propose a method of teaching the accounting cycle that focuses on the substance of the steps, not just their form. I further propose that this method be used as a framework to teach many of the subjects in financial accounting. Lastly, I surveyed accounting students in my intermediate accounting and advanced accounting classes regarding the presentation of the accounting cycle.

\subsection{The Present Cycles}

In the nineteen accounting textbooks reviewed for this paper, the accounting cycle is presented on a continuum of a description, in Edmonds et. al., up to ten different steps in five different texts. The result of the review is presented in Exhibit 1 in the appendix. All but two of these textbooks are recent publications. I reviewed two older textbooks just to indicate the description of the accounting cycle has not change over the last thirty years.

$\overline{\text { Readers with comments }}$ or questions are encouraged to contact the author via email. 
The first step for most textbooks is a transaction or source documents. The second step for most textbooks is to record or journalize the transactions. Nikolai \& Bazley (1997) combine these first two steps. Bedford (1968), Spiceland, Sepe \& Tomassini (2001), and Horgren, Sundem \& Elliott (2002) separate this first step into two parts. All of the textbooks except Antle \& Garstka (2002) have the step of posting following the recording or journalizing step. Antle \& Garstka (2002) go directly from recording transactions to making adjustments. Most textbooks follow posting to the accounts with preparation of a trial balance. Four textbooks do not mention the trial balance in their list of steps. As can be seen in Chart 1, most textbooks listed four steps up to the trial balance. And all of the textbooks clustered around four steps up to the trial balance.

The textbooks do not agree nor cluster around any number of steps after the trial balance as can be seen in Chart 2. For example all of the textbooks list the preparation of financial statements, but six textbooks list the financial statements as the last step. The rest of the textbooks list the preparation of financial statements somewhere in the middle of the process. Two of the textbooks list the preparation of the worksheet as one of the steps in the cycle. Another example of the inconsistency of the presentations of the accounting cycle is shown in the step of posting. Seventeen of the textbooks list posting of daily entries. Only five textbooks list posting of adjusting or closing entries. In summary, the presentation of the accounting cycle is inconsistent across textbooks.

\subsection{The First Cycle}
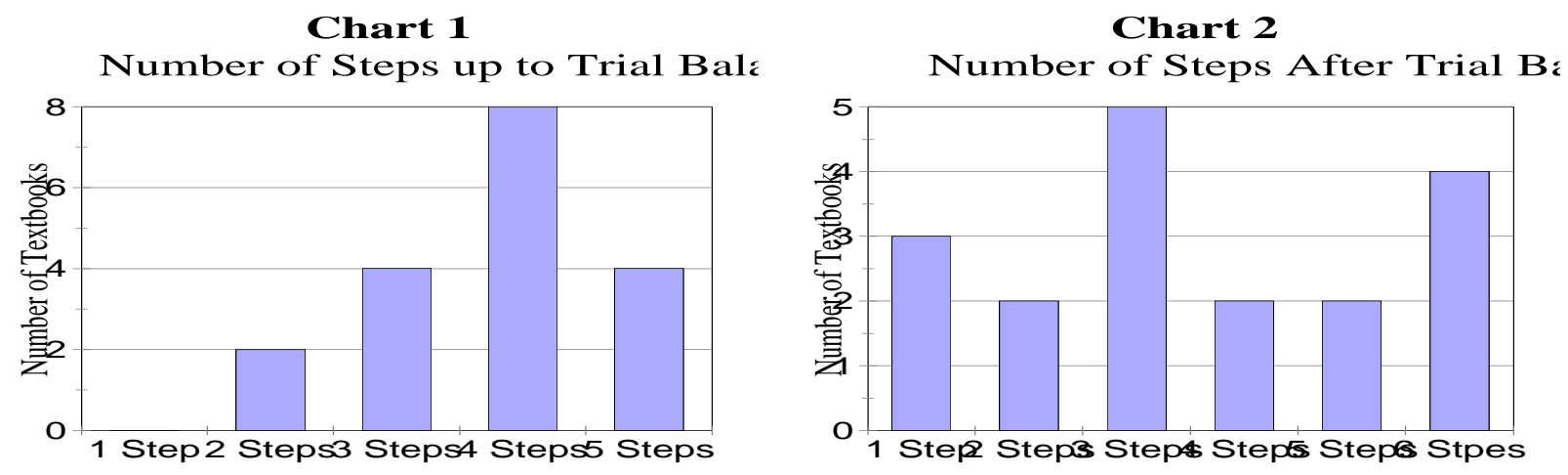

Over the past few years, I have developed a different view of the accounting cycle. When transaction analysis is first presented in the textbook, I present four steps that accountants or others perform to record transactions. These steps are:

1. Events/exchanges/transactions occur.

2. Someone records these transactions.

3. The transactions are summarized.

4. The balance of the accounting equation is verified.

As we analyze transactions and learn that accountants record them in a journal, then post to the ledger accounts, and prepare a trial balance, I change these steps to the following:

1. External transactions occur.

2. Journalize the transactions.

3. Post the entries to accounts.

4. Prepare a Trial Balance at the end of the month.

This last step takes the form of debits equal credits, but it is actually verifying that assets equal liabilities plus owners' equity. 


\subsection{Cycles Within Cycles}

In most textbooks, the chapter that presents recording of daily events is followed by a chapter discussing the adjusting process. In that chapter, I present the same four steps from the perspective of adjustments. The steps are:

1. Internal transactions occur.

2. Journalize adjusting entries.

3. Post the entries to accounts.

4. Prepare adjusted trial balance.

Usually the fourth or fifth chapter in the principles or financial accounting textbooks presents the complete accounting cycle. At this point I present the complete accounting cycle as shown in Exhibit 2.

The three larger boxes contain the same four steps repeated as a daily cycle, an adjusting cycle, and a closing cycle. The first step in each box represents an event, an exchange, a transaction, or a condition that will result in a journal entry. The second step is the recording of the entry. The third step is the posting to the accounts in the ledger, which is the summarizing step. Lastly, the equality of the accounting equation (or debits and credits) is verified.

At this point I discuss the cyclical nature of the process. The daily cycle lasts until the end of the month. At that time, if no financial statements are to be prepared, the daily cycle is started for the next month. If financial statements are to be prepared, the accounts must be adjusted to reflect all transactions or events that have occurred, whether internal or external. I explain that the accountant starts with the daily trial balance and gathers evidence regarding the actual balances of the accounts. With this information the adjusting steps are performed. Then the financial statements may be prepared.

If the company has not reached the end of its fiscal year, the accounts are not closed. The cycle then starts back at the beginning of the daily cycle. If the company has reached the end of the fiscal year, the accounts are closed by going through the four steps in the closing cycle. After the closing cycle the process starts at the beginning for the next fiscal year. The above explanation is stated briefly here. The discussion in class is much more detailed as the various textbook discussions of the accounting cycle.

\subsection{The Cycle As A Tool}

Once the complete diagram in Exhibit 2 is present to the class, I point out that these steps represent what must be accomplished, but it does not indicate the type of system used to accomplish these steps, nor who accomplishes these steps.

As to the first question, these steps may be accomplished in a completely manual system, as is usually explained in accounting textbooks. But in today's computer environment, these steps may be completed electronically. A worksheet may be used to prepare the information to accomplish the steps, and that worksheet may be paper or an electronic spreadsheet. Journal entries are made, in both a manual system and a computer based system, in several different special journals as well as a general journal.

Who completes the steps is another matter. In accounting textbooks, it is the accountant who journalizes entries, posts to accounts, prepares the trial balance and the financial statements. Textbooks are just beginning to note the role of computer systems in the process. In Exhibit 3, I indicate who may accomplish each step.

The first step in daily cycle is usually evidenced by a source document. The second step may be accomplished by one of three parties. The accountant may record the entry from a source document. An example of a transaction recorded by an accountant would be the purchase of land and building. This transaction is a complex one that will involve management, the company lawyer and the accountant at the minimum. 
The second step may be accomplished by an employee other than the accountant. For example, in many retail stores, the clerk may scan the bar code on the merchandise. If the cash register is a computer, not only will the sale be recorded as a debit to cash or accounts receivable and a credit to sales, but the debit to cost of goods sold and the credit to inventory will be recorded. Also subsidiary records will be updated. If the sale causes inventory to drop below a given level, the computer may trigger a reorder of the merchandise.

The second step may also be completed automatically be the computer system. For example, inventory coming off the delivery truck on a conveyer may pass a scanner that reads the bar code and records a debit to inventory and a credit to accounts payable.

The last two steps in the daily cycle (and the adjusting cycle and the closing cycle) are automatically completed by the computer. Posting and balancing happen instantly as data is entered into the system.

The first step in the adjusting cycle is usually the result of the passage of time of the use of some assets. The accountant may accomplish the second step because some human action is necessary to determine an amount used or accrued. For example, the inventory of supplies is reported to the accountant who makes the adjusting entry.

The computer may automatically record adjusting entries for any events which only require the passage of time. For example, accrual of interest on a bond with a premium. Actually, once the terms of a bond are entered into a computer, all of the entries relative to a bond issue could be completed automatically at the proper time. The only human intervention would be that required by internal control procedures, i.e., sign the check (manually or with a check signing machine).

Once the adjusting cycle is complete, the computer can print the financial statement. The accountant may have to review the presentation to reflect Statements of Financial Accounting Standards and write the footnotes that are not boiler plate.

The closing cycle should be automatic. The only human input to the process would be to indicate that the fiscal year has passed. The post-closing trial, or any trial balance, could be printed with the proper keystroke.

\subsection{Closing The Cycle}

Once I review Exhibit 3, I focus on those steps the students need to learn as accountants. Those steps are the second step in the daily cycle and the adjusting cycle, and the preparation of financial statements and footnotes. In subsequent chapters in the first course in accounting and in intermediate accounting, I use the accounting cycle as a way to tie the various topics together. In each new chapter I start by indicating the new daily entries adjusting entries and financial statement presentation and disclosure that will be covered. I ask the students to try to relate the new material to what they have already learned. At the beginning of the intermediate accounting courses, I give a quiz asking the steps in the accounting cycle. My purpose is to begin the class with a framework to tie the material together.

The feedback from students has been favorable. The comments indicate that this presentation is more clear than the textbook. They also state that this presentation is easy to follow and understand. Even though this presentation has more steps, the students comment that is simpler. 
Exhibit 3 - Accounting Cycle

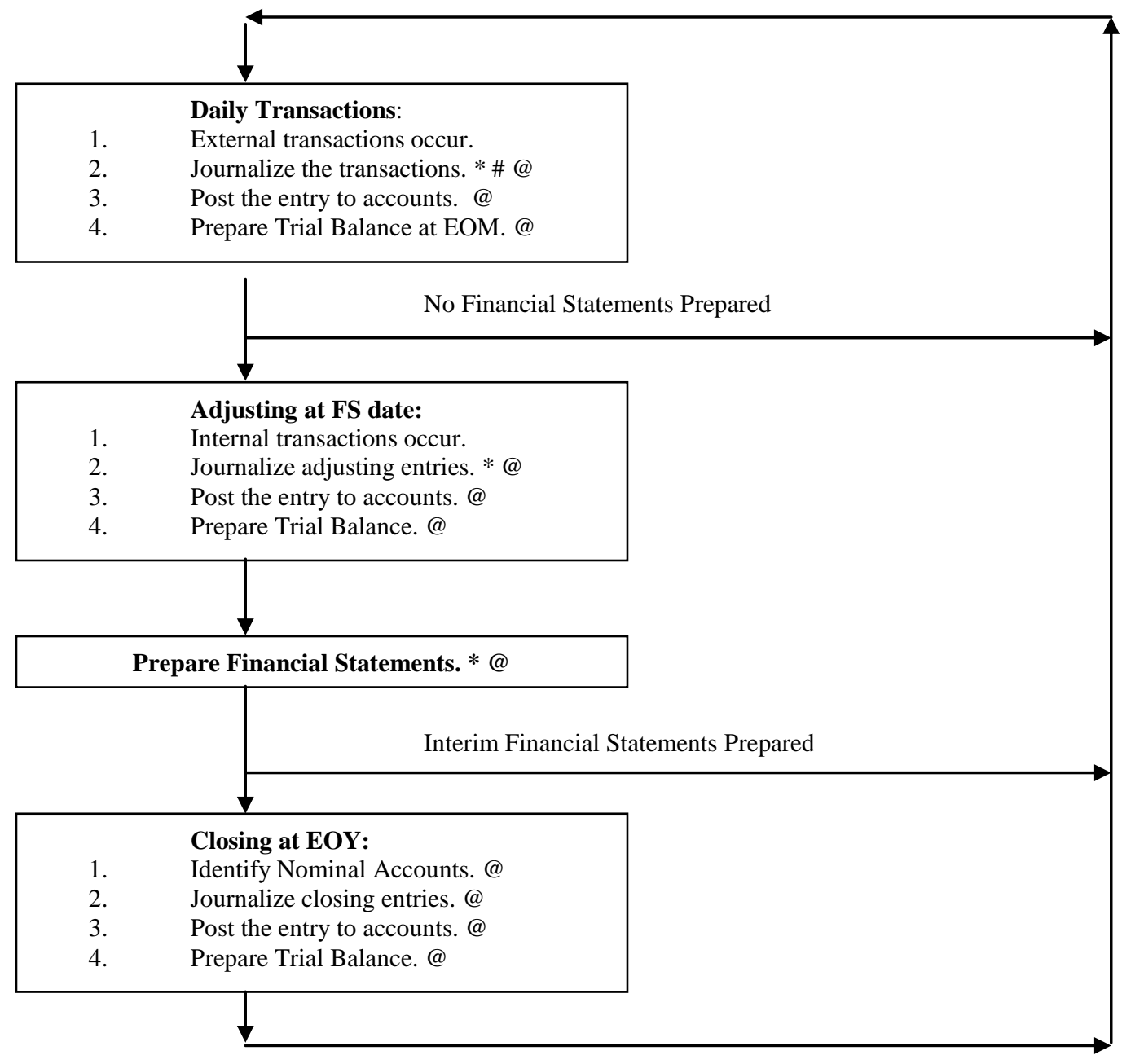

* - These steps may be accomplished by the Accountant.

@ - These steps may be accomplished automatically by a computer.

\# - These steps may be accomplished by a person other than an accountant. 


\section{Appendix}

\begin{tabular}{|c|c|c|c|c|c|c|c|c|c|}
\hline \multicolumn{10}{|c|}{ Exhibit 1 - Accounting Textbooks By Author } \\
\hline Steps In Cycle & $\begin{array}{c}\text { Albrect, Stice, } \\
\text { Stice, Skousen \& } \\
\text { Swain }\end{array}$ & Antle \& Garstka & $\begin{array}{l}\text { Bierman \& } \\
\text { Drebin }\end{array}$ & Edmonds Et.Al. & Heintz \& Perry & $\begin{array}{l}\text { Horngren, } \\
\text { Sundem \& } \\
\text { Elliott }\end{array}$ & $\begin{array}{l}\text { Ingram \& } \\
\text { Baldwin }\end{array}$ & $\begin{array}{l}\text { Jones, Werner, } \\
\text { Terrell \& Terrell }\end{array}$ & $\begin{array}{l}\text { Kimmel, } \\
\text { Weygandt \& } \\
\text { Kieso }\end{array}$ \\
\hline 1 & Analyze Trans. & Analyze Trans. & $\begin{array}{l}\text { Obtain Source } \\
\text { Docs }\end{array}$ & $\begin{array}{l}\text { Descript. } \\
\text { Only }\end{array}$ & $\begin{array}{l}\text { Analyze Source } \\
\text { Docs }\end{array}$ & Transactions & $\begin{array}{l}\text { Obtain Data } \\
\text { From Business } \\
\text { Activity }\end{array}$ & Analyze Trans & $\begin{array}{l}\text { Analyze } \\
\text { Business Trans }\end{array}$ \\
\hline 2 & Record Trans. & Record Trans. & $\begin{array}{l}\text { Jounalize } \\
\text { Entries }\end{array}$ & & $\begin{array}{l}\text { Journalize } \\
\text { Trans }\end{array}$ & Documents & $\begin{array}{l}\text { Record Trans In } \\
\text { Accounts }\end{array}$ & Journalize Trans & Journalize Trans \\
\hline 3 & $\begin{array}{l}\text { Summarize } \\
\text { 1. Post } \\
\text { 2. Prepare TB }\end{array}$ & $\begin{array}{l}\text { Make } \\
\text { Adjustments }\end{array}$ & Post To Ledger & & Post To Ledger & Journal & $\begin{array}{l}\text { Update Account } \\
\text { Balances }\end{array}$ & $\begin{array}{l}\text { Post Trans To } \\
\text { General Ledger }\end{array}$ & $\begin{array}{l}\text { Post To } \\
\text { Accounts }\end{array}$ \\
\hline 4 & $\begin{array}{l}\text { Prepare Reports } \\
\text { (FS) (Adj \& } \\
\text { Close) }\end{array}$ & $\begin{array}{l}\text { Close Temp } \\
\text { Accts }\end{array}$ & Balance Accts & & Prepare TB & Ledger & $\begin{array}{l}\text { Make End Of } \\
\text { Period Adjust }\end{array}$ & Prepare TB & $\begin{array}{l}\text { Prepare Trail } \\
\text { Balance }\end{array}$ \\
\hline 5 & & Prepare FS & Prepare TB & & $\begin{array}{l}\text { Prepare } \\
\text { Adjustments }\end{array}$ & Trial Balance & Prepare FS & Adjust Accounts & $\begin{array}{l}\text { Journalize And } \\
\text { Post Adjusting } \\
\text { Entries }\end{array}$ \\
\hline 6 & & & $\begin{array}{l}\text { Adjusting } \\
\text { Entries }\end{array}$ & & Complete WS & $\begin{array}{l}\text { Financial } \\
\text { Statements }\end{array}$ & $\begin{array}{l}\text { Close The } \\
\text { Books }\end{array}$ & $\begin{array}{l}\text { Prepare } \\
\text { Financial } \\
\text { Statements }\end{array}$ & $\begin{array}{l}\text { Prepare } \\
\text { Adjusted Trial } \\
\text { Balance }\end{array}$ \\
\hline 7 & & & Closing Entries & & Prepare FS & & & $\begin{array}{l}\text { Prepare And } \\
\text { Post Closing }\end{array}$ & $\begin{array}{l}\text { Prepare } \\
\text { Financial } \\
\text { Statements }\end{array}$ \\
\hline 8 & & & Prepare FS & & $\begin{array}{l}\text { Journal Adj } \\
\text { Entires }\end{array}$ & & & $\begin{array}{l}\text { Prepare Post } \\
\text { Closing TB }\end{array}$ & $\begin{array}{l}\text { Journalize And } \\
\text { Post Closing } \\
\text { Entries }\end{array}$ \\
\hline 9 & & & & & $\begin{array}{l}\text { Journal Closing } \\
\text { Entries }\end{array}$ & & & & $\begin{array}{l}\text { Prepare Post } \\
\text { Closing TB }\end{array}$ \\
\hline 10 & & & & & $\begin{array}{l}\text { Prepare Post } \\
\text { Closing TB }\end{array}$ & & & & \\
\hline
\end{tabular}




\section{Appendix continued}

\begin{tabular}{|c|c|c|c|c|c|c|c|c|c|c|}
\hline \multicolumn{11}{|c|}{ Exhibit 1 (Continued) - Accounting Textbooks By Author } \\
\hline Steps In Cycle & $\begin{array}{l}\text { Larson, Wild } \\
\& \text { Chiapetta }\end{array}$ & $\begin{array}{l}\text { Needles \& } \\
\text { Powers } \\
\text { (Crosson) }\end{array}$ & $\begin{array}{c}\text { Stickney \& } \\
\text { Weil }\end{array}$ & $\begin{array}{l}\text { Nikolai \& } \\
\text { Bazley }\end{array}$ & $\begin{array}{c}\text { Skousen, Stice } \\
\text { \& Stice }\end{array}$ & $\begin{array}{c}\text { Dyckman, } \\
\text { Dukes \& Davis }\end{array}$ & $\begin{array}{l}\text { Spiceland, } \\
\text { Sepe \& } \\
\text { Tomassini }\end{array}$ & $\begin{array}{c}\text { Kieso, } \\
\text { Weygandt \& } \\
\text { Warfield }\end{array}$ & Bedford & $\begin{array}{c}\text { Porter \& } \\
\text { Norton }\end{array}$ \\
\hline 1 & Analyze Trans & Analyze Trans & $\begin{array}{l}\text { Results Of } \\
\text { Events \& } \\
\text { Trans }\end{array}$ & $\begin{array}{l}\text { Record Daily } \\
\text { Trans }\end{array}$ & $\begin{array}{l}\text { Business } \\
\text { Documents }\end{array}$ & Identify Trans & $\begin{array}{l}\text { Source } \\
\text { Documents }\end{array}$ & Identify Trans & $\begin{array}{l}\text { Obtain } \\
\text { Documents }\end{array}$ & $\begin{array}{l}\text { Collect \& } \\
\text { Analyze Info } \\
\text { From Source } \\
\text { Docs }\end{array}$ \\
\hline 2 & Journalize & $\begin{array}{l}\text { Record In } \\
\text { Journal }\end{array}$ & Journalize & $\begin{array}{l}\text { Post To } \\
\text { Ledger }\end{array}$ & $\begin{array}{l}\text { Trans } \\
\text { Recorded In } \\
\text { Journal }\end{array}$ & $\begin{array}{l}\text { Journalize } \\
\text { Trans }\end{array}$ & $\begin{array}{l}\text { Transaction } \\
\text { Analysis }\end{array}$ & Journalize & $\begin{array}{l}\text { Analyze } \\
\text { Transtions }\end{array}$ & $\begin{array}{l}\text { Journalize } \\
\text { Trans }\end{array}$ \\
\hline 3 & Post & $\begin{array}{l}\text { Post To } \\
\text { Ledger \& } \\
\text { Prepare TB }\end{array}$ & $\begin{array}{l}\text { Periodic } \\
\text { Posting To } \\
\text { Ledger }\end{array}$ & $\begin{array}{l}\text { Prepare \& Post } \\
\text { Adjusting } \\
\text { Entries }\end{array}$ & $\begin{array}{l}\text { Post To } \\
\text { Ledger }\end{array}$ & $\begin{array}{l}\text { Post To } \\
\text { Ledger }\end{array}$ & $\begin{array}{l}\text { Record In } \\
\text { Journal }\end{array}$ & $\begin{array}{l}\text { Post To } \\
\text { Ledger }\end{array}$ & $\begin{array}{l}\text { Record In } \\
\text { Journal }\end{array}$ & $\begin{array}{l}\text { Post To } \\
\text { Accounts }\end{array}$ \\
\hline 4 & Prepare TB & $\begin{array}{l}\text { Adjust } \\
\text { Accounts \& } \\
\text { Prepare TB }\end{array}$ & $\begin{array}{l}\text { Prepare } \\
\text { Unadjusted TB }\end{array}$ & Prepare FS & Trial Balance & Prepare TB & $\begin{array}{l}\text { Post To } \\
\text { Ledger }\end{array}$ & Prepare TB & $\begin{array}{l}\text { Post To } \\
\text { Ledger }\end{array}$ & $\begin{array}{l}\text { Prepare } \\
\text { Worksheet }\end{array}$ \\
\hline 5 & Adjust & $\begin{array}{l}\text { Close } \\
\text { Accounts \& } \\
\text { Prepare TB }\end{array}$ & $\begin{array}{l}\text { Adjustment Of } \\
\text { TB }\end{array}$ & $\begin{array}{l}\text { Prepare \& Post } \\
\text { Closing } \\
\text { Entries }\end{array}$ & Adjustments & $\begin{array}{l}\text { Journal \& Post } \\
\text { Adjustments }\end{array}$ & $\begin{array}{l}\text { Prepare Trial } \\
\text { Balance }\end{array}$ & Adjust & Prepare TB & Prepare FS \\
\hline 6 & $\begin{array}{l}\text { Prepare } \\
\text { Adjusted TB }\end{array}$ & Prepare FS & Prepare FS & & $\begin{array}{l}\text { Financial } \\
\text { Statements }\end{array}$ & $\begin{array}{l}\text { Prepare Adjust } \\
\text { TB }\end{array}$ & $\begin{array}{l}\text { Record } \\
\text { Adjustments }\end{array}$ & Adjusted TB & $\begin{array}{l}\text { Prepare } \\
\text { Accounting } \\
\text { Reports }\end{array}$ & $\begin{array}{l}\text { Record \& Post } \\
\text { Adjustments }\end{array}$ \\
\hline 7 & Prepare FS & & & & $\begin{array}{l}\text { Closing } \\
\text { Entries }\end{array}$ & Prepare FS & $\begin{array}{l}\text { Prepare } \\
\text { Adjusted TB }\end{array}$ & Prepare FS & & $\begin{array}{l}\text { Close The } \\
\text { Accts }\end{array}$ \\
\hline 8 & Close & & & & $\begin{array}{l}\text { Post Closing } \\
\text { TB }\end{array}$ & $\begin{array}{l}\text { Journal \& Post } \\
\text { Closing } \\
\text { Entries }\end{array}$ & Prepare FS & Closing & & \\
\hline 9 & $\begin{array}{l}\text { Prepare Post } \\
\text { Closing TB }\end{array}$ & & & & & $\begin{array}{l}\text { Prepare Post } \\
\text { Closing TB }\end{array}$ & $\begin{array}{l}\text { Close Temp } \\
\text { Accounts }\end{array}$ & $\begin{array}{l}\text { Post Closing } \\
\text { TB }\end{array}$ & & \\
\hline 10 & $\begin{array}{l}\text { Reverse } \\
\text { Optional }\end{array}$ & & & & & $\begin{array}{l}\text { Journal \& Post } \\
\text { Reversing }\end{array}$ & $\begin{array}{l}\text { Prepare Post } \\
\text { Closing TB }\end{array}$ & $\begin{array}{l}\text { Reversing } \\
\text { (Optional) }\end{array}$ & & \\
\hline
\end{tabular}




\section{References}

1. Albrecht, W. S., J. D. Stice, E. K. Stice, K. F. Skousen \& M. R. Swain. 2002. Accounting Concepts \& Applications $8^{\text {th }}$ ed. Cincinnati: Southwestern.

2. Antle R. \& S. J. Garstka.2002. Financial Accounting. Cincinnati: Southwestern.

3. Bedford, Norton. 1968. Introduction to Modern Accounting. New York: The Ronald Press.

4. Bierman H. \& A. R. Drebin. 1972. Financial Accounting, $2^{\text {nd }}$ ed. New York: The Macmillan Company.

5. Dyckman, T. R., R. E. Dukes \& C. J. Davis. 1998. Intermediate Accounting, $4^{\text {th }}$ ed. Boston: Irwin McGrawHill.

6. Edmonds, T. P., F. M. McNair, E. E. Milam, P. R. Olds \& C. D. Edmonds. 2000. Fundamendal Financial Accounting Concepts, $3^{\text {rd }}$ ed. Boston: Irwin McGraw-Hill.

7. Heintz J. A. \& R. W. Perry. 1999. College Accounting, $16^{\text {th }}$ ed. Cincinnati: Southwestern.

8. Horngren, C. T., G. L. Sundem \& J. A. Elliott. 2002. Introduction to Financial Accounting, $8^{\text {th }}$ ed. Upper Saddle River: Prentice Hall.

9. Ingram R. W. \& B. A. Baldwin. 2001. Financial Accounting Information for Decicions, $4^{\text {th }}$ ed. Cincinnati: Southwestern.

10. Jones, K. H., M. L. Werner, K. P. Terrell \& R. L. Terrell. 2000. Introduction to Financial Accounting, $2^{\text {nd }}$ ed. Saddle River: Prentice Hall.

11. Kieso, Weygandt \& Warfield. 2001 Intermediate Accounting, $10^{\text {th }}$ ed. New York: John Wiley \& Sons.

12. Kimmel, P. D., J. J. Weygandt \& D. E. Kieso. 2000. Financial Accounting Tools for Business Decision Making, $2^{\text {nd }}$ ed. New York: John Wiley \& Sons.

13. Larson, K. F., J. J. Wild \& B. Chiappetta. 2002. Fundamental Accounting Principles, $16^{\text {th }}$ ed. Boston: Irwin McGraw-Hill.

14. Needles B. E. \& M. Powers. 2000. Financial Accounting, $7^{\text {th }}$ ed. Boston: Houghton Mifflin Company.

15. Needles B. E. \& M. Powers, Principles of Financial Accounting, 2002 ed. Boston: Houghton Mifflin Co.

16. Needles, B. E., M. Powers \& S. V. Crosson, Principles of Accounting, 2002 ed. Boston: Houghton Mifflin Company.

17. Nikolai L. A. \& J. D. Bazley. 1997. Intermediate Accounting $7^{\text {th }}$ ed. Cincinnati: Southwestern.

18. Porter, G. A. \& C. L. Norton. 2001. Financial Accounting: The Impact on Decision Makers, $3^{\text {rd }}$ ed.Orlando: Harcourt, Inc.

19. Skousen, K. F., E. K. Stice \& J. D. Stice. 2000. Intermediate Accounting, $14^{\text {th }}$ ed. Cincinnati: Southwestern.

20. Spiceland, J. D., J. F. Sepe \& L. A. Tomassini. 2001. Intermediate Accounting, $2^{\text {nd }} e d$. Boston: Irwin McGraw-Hill.

21. Stickney C. P. \& R. L. Weil. 1997. Financial Accounting: An Introduction to Concepts, Methods \& Uses, $8^{\text {th }}$ ed. Fort Worth: The Dryden Press. 